\title{
Calculating river discharge coupling unmanned aerial vehicles (UAVs) and satellite remote sensing in ungauged basins
}

\author{
Shengtian Yang ${ }^{1}$, Juan Wang ${ }^{1}$, Pengfei Wang ${ }^{1}$, Huiping Liu ${ }^{1}$, and Tongliang Gong ${ }^{2}$ \\ ${ }^{1}$ Beijing Normal University \\ ${ }^{2}$ Tibet Institute of Water Resource Survey Planning Design and Research
}

July 20, 2020

\begin{abstract}
How to get the discharge information of the river becomes a hot topic in global research. However, most river discharge measurement methods involve long cycles, low efficiency, and transdisciplinary expertise. This makes it impossible to assess river flows in ungauged basin rapidly. With the improvement of accuracy of hydrological parameters and variables, the data obtained by remote sensing method can not satisfy the hydrological calculation. This study presents a new method to rapidly assessing river discharge coupling remote sensing images and UAVs. We selected eight typical river-course cross-sections in Bortala river and Jing river to calculate river discharge. Construction of river cross-section shape by UAV data combined with groundwater level monitoring. Dividing the reach and generalizing the relationship of hydraulic geometry of the reach. By extracting the river width, the river discharge of river cross-section was estimated. The results showed that the calculated results were consistent with the measured data and the accuracy was above $90 \%$. This paper discusses the application of this method in satellite remote sensing. The results compared with the measured daily data of hydrological station, and the accuracy of the calculated results can reach above $85 \%$. The method used in this study for calculating river discharge based on a combination of UAV and satellite remote sensing can effectively promote research progress into basin river discharge, and provide an important reference for river discharge monitoring in ungauged basins.
\end{abstract}

\section{Hosted file}

manuscript.doc available at https://authorea.com/users/344539/articles/471009-calculatingriver-discharge-coupling-unmanned-aerial-vehicles-uavs-and-satellite-remote-sensing-inungauged-basins

\section{Hosted file}

Figures.doc available at https://authorea.com/users/344539/articles/471009-calculatingriver-discharge-coupling-unmanned-aerial-vehicles-uavs-and-satellite-remote-sensing-inungauged-basins

\section{Hosted file}

Tables.doc available at https://authorea.com/users/344539/articles/471009-calculatingriver-discharge-coupling-unmanned-aerial-vehicles-uavs-and-satellite-remote-sensing-inungauged-basins 